\title{
Boundaryless Career and Career Outcomes: The Mediating Role of Individual Career Management Behaviours
}

\author{
Irene Nikandrou* \\ Eleanna Galanaki
}

\begin{abstract}
The main objective of this paper is to study individuals' attitude towards mobility both psychological and physical and the behavioural paths that people may use to experience career success. In a structural equation model, we consider boundaryless career attitudes and the mediating role of career management behaviours to career outcomes. Psychological mobility appears to be a better predictor of career satisfaction and career advancement than physical mobility. All career strategies have a positive effect on career advancement, except for extended work involvement. Relationships oriented career strategies are not linked with career satisfaction. Physically mobile people adopt to a lesser extent relationship- oriented career strategies. Our results showed that people with a psychological mobility attitude are more likely to achieve career satisfaction through remaining flexible in their career. This knowledge is very important for practitioners and managers working with psychologically mobile personnel, as it underlines the need for employers to provide opportunities for training, skill development and challenging work. The study adds to the existing literature in that it provides empirical evidence regarding the career behavioural paths individuals with a boundaryless career attitude may use when they expect to advance their careers. Our findings help us understand better the psychological mobility attitude which has been examined less in the literature.
\end{abstract}

Keywords: Career Attitudes; Career Strategies; Career Satisfaction; Career Success; Boundaryless Career

JEL Classification: M, M00

* Irene Nikandrou and Eleanna Galanaki are at Athens University of Economics and Business, Athens, Greece. 


\section{Introduction}

As the business and the socio-economic environment becomes more and more complex and unpredictable in terms of changes, employees should be more flexible and adaptable to new and most of the times ambiguous and unknown conditions. These trends have placed greater demands on the individual to manage his/her career. In this terrain, protean and boundaryless career attitudes are the two types of career orientations that have influenced the most the organizational literature in the past decades. These two career models are characterized by self-initiated career behaviors and mobility and have little to do with traditional careers initiated by the organization (Briscoe and Hall, 2002; Hall, 1996). Despite the fact that the two concepts have been very influential in the career literature, empirical research is still in its infancy (De Vos and Soens, 2008; Eby, Butts and Lockwood, 2003; Segers, Inceoglu, Vloeberghs, Bartram, and Henderickx, 2008).

In the literature, the concept of boundaryless career has been linked to mobility. According to Sullivan and Arthur (2006) psychological mobility refers to the perception of the capacity of the individual to make transitions, while physical mobility refers to the actual transition across jobs, employers or industries. The majority of the research up to now emphasizes physical mobility. Briscoe, Hall and DeMuth (2006) support that even though people may hold boundaryless attitudes they may not always have an inclination towards physical mobility. People need a certain level of stability and security, as well as a certain level of challenge, variety and novelty (Baruch, 2006). Individuals may not need to actually change a job or an employer. They may need to "move" to something else that may be complimentary to what they do or that it may add to their existing activities. Sullivan and Arthur (2006) propose that psychological and physical mobility are more likely to unfold sequentially as individuals grow and enhance their career competencies. Baruch (2006) supports a more balanced approach to career management by arguing that both traditional and contemporary career systems are valid and exist in practice. However, even though organizations are still important in managing career, the emphasis is on the individuals to manage their careers. Indeed, individuals experience new realities in societal and organizational life and they must be able to face more crises in their working lives. Thus, the person must be at the center of his/her career and actively explore and form the options to remain marketable.

Briscoe and Filkenstein (2009) call for additional empirical research to better understand the boundaryless perspective. Identifying those behaviors that are related to boundaryless career attitudes are important to better understand the concept of boundaryless career.

In this study, we explore both psychological and physical mobility attitudes. We try to understand the link flowing from boundaryless career attitude to perceived career success through individuals' career strategies. There is a shift in defining ca- 
reers from a succession of related jobs (Wilensky, 1961), to a combination and sequence of roles (Super, 1980), to an evolving sequence of a person's work experiences over time (Arthur, Hall and Lawrence, 1989). As careers have been linked to work experiences both objective and subjective elements have been brought to attention. The subjective career elements refer to attitudes, orientations and outcomes that are relevant to an individual concerning his/her career. People have a certain mindset about their careers that reflects the way they see and evaluate their career options and the behavioral tendency they have to behave in certain ways (Briscoe and Hall, 2006; Segers et al, 2008). The objective career elements are mostly concerned with observable behaviors, activities, moves and measurable outcomes. In our work, we raise the question of how boundaryless career attitudes are related to the adoption of specific career management strategies which contribute to perceived career success. Our work contributes to the existing literature by examining individuals' attitude towards mobility both psychological and physical and the behavioral paths that people may use to experience career success.

More specifically, this paper adopts a subjective approach to careers encompassing personal attitudes and choices regarding career as predictors of career outcomes (success). We consider boundaryless career orientations (career attitude), career management strategies (work-related choices) and career satisfaction and career advancement. In a structural equations model, career management strategies are, first, considered as the outcome of the boundaryless attitudes and, second, as a mediator in the relationship between career attitudes and subjective career outcomes.

Figure 1: Rough graphic outline of the research relations under study
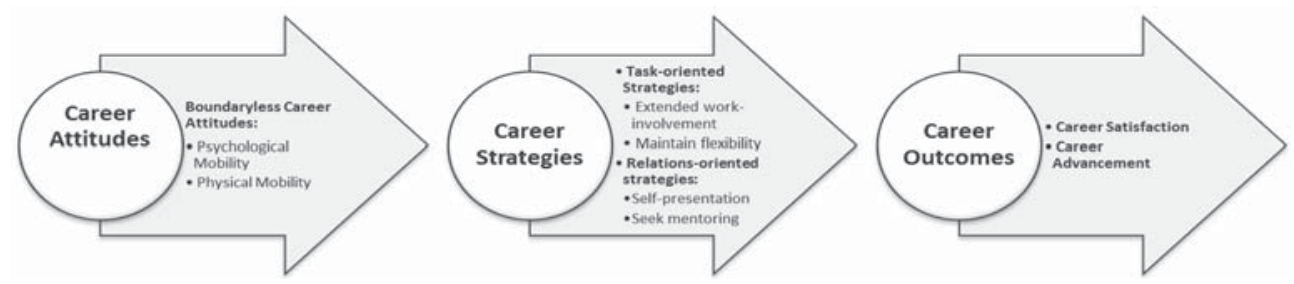

Figure 1 outlines the overall conceptual relations between the three sets of variables that we set on to examine.

The paper is organized in four parts. Next, we present the research framework and the hypotheses to be tested. The methodological concerns are then examined. The results from the study are then presented and the paper concludes with a discussion of the findings, the limitations and several implications for future research. 


\section{Research Hypotheses}

\section{Career Outcomes}

One of the most frequently cited definition of career success is that of Judge, Cable, Boudreau, and Bretz (1995), according to which career success is defined "as the positive psychological or work-related outcomes or achievements one accumulates as a result of work experiences" (p.486). A similar definition has also been given by Arthur, Khapova and Wilderom (2005) who emphasize that career success has two elements. First, the outcomes must be personally desirable and psychologically positive (subjective part) and second, for outcomes to be considered achievements they are likely to rely on (largely objective) social comparisons (p.179). So, career outcomes encompass both objective -observable, measurable and verifiable achievements, such as pay, hierarchical position, promotion, occupational status- and subjective (individual's feelings and reactions regarding his/her career, such as career satisfaction) measures to assess individuals' work experiences (Abele and Spark, 2009; Gunz and Heslin, 2005; Ng et al, 2005).

In the boundaryless career model the responsibility for satisfying career outcomes lies mainly with the individual. Thus, subjective career interpretations become more significant. Arthur et al (2005) review career success literature for 11 years and argue that considerable more empirical researches focus on objective career success measures.

The growing uncertainty and unpredictability in the social and work environments are reflected in the changing nature of careers that place an increased importance in the individual to shape his/her career. Better educated individuals as well as flatter and less hierarchical structures demand a more active role from the individual in managing his/her career. Moreover, the increased intra and inter-firm mobility and decreased commitment to a single organization emphasize the individual's perceptions of what career success means. Arthur et al (2005) support this view by stating that the unpredictability in the environment heightens the significance of subjective career (p.195-6). In this study we use two measures of career outcomes, namely career satisfaction and perceived career advancement. Among subjective career measures, career satisfaction is the one most widely used. In a "boundaryless and protean career world", satisfaction with what one has accomplished in his/her work life is more important in defining success, rather than with making it to the top with lots of money and rewards. In addition, the probability of been promoted either internally or externally with the next years was included as an indicator of subjective evaluation of career advancement. We also study whether evaluations of career advancement lead to perceptions of career satisfaction. 


\section{The Boundaryless Career}

The boundaryless career perspective places the responsibility for the attainment of career goals to the individual (Arthur and Rousseau, 1996). An individual with a boundaryless career attitude takes advantage of opportunities as they appear and is not bounded to a single organization (Briscoe and Hall, 2006). Sullivan and Arthur (2006) define boundaryless career "as one that involves physical and/or psychological career mobility at varying levels" (p.22). Thus, the boundaryless career has two dimensions: psychological and physical mobility. Psychological mobility is concerned with the individual's perceived capacity to move across boundaries that are psychological in nature, such as working in networks. Physical mobility refers to the "actual movement between jobs, firms, occupations, countries" (Sullivan and Arthur, 2006, p. 21). Arthur, Khapova and Wilderom (2005) argue that most research focuses on physical mobility and call for more research on the psychological mobility. Briscoe et al (2006) refer to it as the 'boundaryless mindset', as it is the willingness "to initiate and pursue work-related relationships across organizational boundaries" (p. 31). Miner and Robinson (1994) support that in a boundaryless career the logic of learning underlines career patterns, causing individuals to move between jobs, activities and roles.

We examine the direct effects of the boundaryless career attitude on career outcomes and the indirect effects through its impact on career management strategies. Arthur et al (2005) support that the subjective career success indicators may be more relevant for the psychological mobility dimension of the boundaryless career concept. Segers, et al (2008) examine the potential motivators of the boundaryless career attitude. They suggest that individuals with a physical mobility orientation are more driven by money, status, promotion or interest and less by job security, while individuals with psychological mobility are more driven by autonomy, affiliation, variety and novelty. Thus, individuals with a physical mobility attitude may value career success based on more objective career success criteria, and they may be more engaged in behaviors that promote their status. Moreover, individuals with psychological mobility may define career success in more subjective ways.

H1.: A person with a psychological mobility career attitude will report higher levels of subjective career outcomes.

$\mathrm{H} 2 .:$ A person with a physical mobility career attitude will report lower levels of subjective career outcomes.

\section{Career Management Behaviors}

Career management behaviors refer to an individual's efforts to realize his/her personal career objectives. Individuals set career goals and engage in behaviors that increase the chances of personal and professional success. They are control-seeking 
behaviors that an individual develops to manage his/her career (King, 2004). Gould and Penley (1984, p. 224) defined career strategies as 'behaviors which may be utilized by an individual to decrease the time required for and uncertainty surrounding the attainment of important career objectives'. The strategies involve conscious choices and activities designed to help a person achieve his/her career goals (Greenhaus et al, 2000). Thus, the individual develops a range of behaviors to control his/ her career. King (2004) supports that it is more preferable to use the term behaviors instead of strategies, since these "behaviors may be deployed with strategic intent, in a pre-meditated rational fashion, but they may also be used in an improvised manner as a response to the immediate demands of a particular situation" (p.119).

Different researchers have identified various career self-management behaviors. Gould and Penley (1984) proposed six career strategies individuals can use, that is seeking guidance/mentoring, networking, self-presentation, creating opportunities, extended work involvement and ingratiating behaviors. Guthrie et al (1998) group Gould and Penley's career strategies into relationship-oriented, that involve working through or with other people, and self/work-oriented, that focus on job tasks or the development of career related skills. King $(2001,2004)$ identified three categories of career self-management behaviors, namely influence, positioning and boundary management behaviors. Sturges, Guest, Conway and Davey (2002) support that networking and visibility activities may be important in developing a career within an organization while gaining marketable knowledge and doing practical things such as monitoring job advertisements may be more suited for a career in different organizations.

Irrespective of the typology used, career self-management behaviors are linked to perceptions of control and have been suggested to have a positive impact on career satisfaction (Lee, 2002; King, 2004). In this study we examine a set of career management behaviors based on the typology proposed by Guthrie et al (1998). More specifically, we look at both task-oriented and relationship-oriented career strategies. The former include maintaining flexibility and extended work involvement, while the latter refer to self-presentation and seeking mentoring / networking. Relational career strategies such as mentoring and networking have been associated with both objective (Apospori et al, 2006; Higgins and Kram, 2001; Kuijpers et al, 2006; Wanberg et al, 2003) and subjective career success (Allen et al, 2004; Kuijpers et al, 2006; Nabi, 2003; Wanberg et al, 2003). Contrary to these findings, De Vos and Soens (2008) failed to provide evidence for career self-management behaviors (networking and visibility) having an impact on career outcomes.

H3.: A person adopting a task oriented career strategy, that is work involvement and maintaining flexibility, will report higher levels of career outcomes.

H4.: A person adopting a relationship oriented career strategy, that is seeking mentoring and self-presentation, will report higher levels of career outcomes.

As Arthur et al (2005) mention the physical mobility attitude focuses on the "opportunity for inter-organizational mobility" (p.181) and not the actual movement. The 
person may be alert to move both psychological and physically, thus engaging in behaviors that make him/her more mobile. The needs for autonomy, variety and novelty individuals with a psychological mobility attitude have may motivate them towards behaviors that make them be more open to experience and flexible, while their need for affiliation makes them more relationship oriented (Segers et al, 2008). Individuals with a physical mobility attitude driven more by money, status and promotion may engage more in task relationship career management behaviors, while they develop and maintain relationships that help them be mobile. Inter-organizational mobility increases the role of individual in managing his/her career.

H5.: A person with a boundaryless career attitude, that is psychological and physical mobility career attitudes, will adopt both task-oriented and relationship-oriented career strategies.

\section{Mediating Effects of Career Management Strategies}

We have argued that we expect to find a direct impact of boundaryless career attitudes on career outcomes. We also believe that a person with such attitudes will engage in career behaviors that promote his/her career outcomes. King (2004) proposes a framework to study career self-management behaviors. She identifies desire for control and self-efficacy as possible causes for career self-managing behaviors which in turn result in career desired outcomes. A boundaryless career attitude, mainly the psychological mobility attitude, assumes that a person has a desire for control over his/her career. Colakogly (2011) supports that career boundarylessness (the physical mobility dimension) leads to two career competencies of knowing-why and knowing-how which in turn lead to subjective career success through career autonomy. Thus, we expect career management behaviors to mediate the relationship between psychological and physical mobility and career outcomes.

H6.: The career strategies that a person adopts will mediate the relationships between boundaryless career attitudes and career outcomes.

\section{Research Methodology}

\section{Sample}

431 respondents working in Greek organizations participated in our survey from spring to autumn 2012. The questionnaire was administered through contacts provided by undergraduate and graduate students. One hundred and seventy-six undergraduate and graduate students provided 635 names and contact details of employees to participate in our survey. After contacting the persons 456 individuals agreed to participate; the participation rate was $72 \%$. Four hundred and thirty-one of the 
456 returned questionnaires were usable. Researchers made a conscious attempt to achieve a somewhat representative, quota sample by giving instructions mainly regarding gender, age, and occupation. Thus, the different demographic traits (gender, age, education and occupation) are more or less represented to the same extent as in the Greek population. As can be seen in Table 1, below, an equal participation of each gender was achieved, while the age of the respondents is close to the normal distribution (with skewness $=0.007$ and kurtosis $=1$, i.e. somewhat flatter than a normal distribution with a wider peak).

Table 1 gives a brief description of our sample.

Table 1: Description of the 431-cases sample

\begin{tabular}{|l|l|r|}
\hline \multicolumn{1}{|c|}{ Age } & & $\begin{array}{c}\text { Aver. } \mathbf{4 4 . 7} \\
\text { SD=11,686 }\end{array}$ \\
\hline \multirow{4}{*}{ Gender } & Male & $49.7 \%$ \\
\hline & Female & $50.3 \%$ \\
\hline \multirow{4}{*}{ Marital Status } & Primary & $2 \%$ \\
\cline { 2 - 3 } & Secondary & $27.5 \%$ \\
\cline { 2 - 3 } & Higher & $52 \%$ \\
\cline { 2 - 3 } & Postgraduate & $18.6 \%$ \\
\hline \multirow{5}{*}{ Occupation } & Single & $32.5 \%$ \\
\cline { 2 - 3 } & Married & $33.2 \%$ \\
\cline { 2 - 3 } & Separated & $29.2 \%$ \\
\hline \multirow{5}{*}{ Position in hierarchy (if employed) } & Entrepreneur & $8.6 \%$ \\
\cline { 2 - 3 } & Self-Employed & $14.4 \%$ \\
\cline { 2 - 3 } & Employee & $69.5 \%$ \\
\cline { 2 - 3 } & Other/not replied & $7.5 \%$ \\
\hline & Employees- Lower Management & $27.1 \%$ \\
\cline { 2 - 3 } & Middle management & $24.5 \%$ \\
\cline { 2 - 3 } & Higher/Top management & $7.6 \%$ \\
\cline { 2 - 3 } & Other/not replied & \\
\hline
\end{tabular}

\section{Measurement and Scales}

All of the scales described below were represented to on a 5-point Likert scale from "strongly disagree" (1) to "strongly agree" (5).

Boundaryless Career Attitudes. The Boundaryless Career attitudes were assessed with the use of the Briscoe et al (2006) questionnaire. Thirteen items were used to evaluate the boundaryless career attitudes (psychological mobility and physical mobility).

The psychological mobility career attitude measures "the boundaryless mindset or the general attitude to working across organizational boundaries" (Briscoe et al, 
2006, p. 33). It consisted of 8 items, some of which were "I seek job assignments that allow me to learn something new", "I enjoy working with people outside of my organization", "I enjoy jobs that require me to interact with people in many different organizations". The Cronbach's a for this scale was 0,8695 and the composite reliability 0,8994 .

The physical mobility career attitude measures "organizational mobility preference or the strength of interest in remaining with a single (or multiple) employer(s)" (Briscoe et al, 2006, p.33). It consisted of 5 items some of which were "If my organization provided lifetime employment, I would never desire to seek work in other organizations", "If my ideal career I would work for only one organization". The Cronbach's a for this scale was 0,7185 and the composite reliability 0,8147

Career Management Behaviors. The items assessing individuals' adopted career behaviors were measured with the Guthrie et al (1998) scale on career management behaviors. We need to mention that we run a pretest with one hundred and ten parttime graduate students that were working in Greek organizations to whom we administered a questionnaire with all 22 original items as proposed by Guthrie et al (1998). Exploratory factor analysis using Principal Components and Varimax rotation demonstrated that 15 items loaded on four factors. Thus, in this survey we decided to include these 15 items. The set of items contained in the survey and the factor loadings appears in the Appendix.

Four career behaviors were identified, in agreement with the original proposition of Guthrie et al (1998). The four constructed scales measure extended work involvement and maintain career flexibility (self/work-oriented strategies), and self-presentation and seeking mentoring (relationship-oriented strategies). It should be noted that as we included 15 items based on our exploratory factor analysis the career management behavior of seeking mentoring was actually merged with building networks. However, the scale exhibited ideal measurement characteristics.

1) Extended work involvement measures the degree to which an individual spends time for his/her work beyond "regular working time". It was measured with three items, as originally proposed in Guthrie et al. (1998). Example: "I take my work home with me". The Cronbach alpha for this scale was0,7698 and the composite reliability 0,8663 .

2) Maintain career flexibility measures the degree to which an individual develops skills that will help him/her in his/her career. It was measured with four items, for example: "Develop skills that may be needed in future career positions". The Cronbach alpha for this scale was 0,7582 and the composite reliability 0,8453 .

3) Self- presentation measures the degree to which an individual presents him/ herself as competent and effective. It was measured with two items, for example: "I present myself as a person who gets things done". The Cronbach alpha for this scale was 0,8024 and the composite reliability 0,8903 . 
4) Seeking mentoring measures the degree to which an individual is well connected with colleagues and superiors and seeks mentoring. It was measured with six items, for example: "I get career guidance from supervisors". The Cronbach alpha for this scale was 0,7714 and the composite reliability 0,8392 .

Career Satisfaction. Career Satisfaction measures the degree to which the person is satisfied with his/her career. It was measured with two research scales which appeared to work interchangeably and form a uniform concept. These two scales were the Greenhaus et. al. (1990) 5-item scale and the Martins et al. (2002) 3- item scale on satisfaction with the career. So, eventually we measured the concept of career satisfaction with 8 questions and the eventual scale exhibited very good statistical characteristics of reliability and validity. The Cronbach alpha was 0,9049, the composite reliability 0,9235 and convergent validity AVE 0,6024).

Career Advancement. The concept of expectation for career advancement was measured with one question, i.e. "It is likely that I get promoted within the next 5 years", as a way to establish not only the current satisfaction with career development but also expectations on career development in the future. The measurement was given on a 5-point Likert scale from "totally agree" to "totally disagree".

\section{Analyses Conducted}

On the data gathered, standard quantitative analysis was conducted (descriptives, correlations, tests for difference of means etc.), with the IBM SPSS Statistics 19 software. In addition to that, Variance-based Structural Equation Modelling was applied, with the use of the SmartPLS software (Ringle et al., 2005). Partial Least Squares (PLS) analysis is a structural equation modelling technique mostly adequate for predictive purposes and smaller sample sizes than the more well- known and amply used covariance-based Structural Equation Modelling techniques (such as AMOS and LISREL) (Hair et al., 2013b, Hair et al., 2013a). PLS has been known and applied by econometrics and statisticians since the late 1970's. In fact, it was introduced concurrently with the most well-known by business researchers, covariance-based SEM techniques. It has recently known a re-surge in business and management research community thanks to numerous collective volumes and special issues in high-impact business journals on its technique and applications (Hair et al., 2013b, Ringle et al., 2012, Hair et al., 2012).

Before running any analysis, it was deemed necessary to run tests in order to elaborate whether single source bias was an issue in our dataset. We needed to control for that, as indeed our data were gathered through a self-report instrument. We had obviously originally attempted to diminish the risk of single source bias through the use of clear grammar and concise scale items, as well as guaranteeing and communicating anonymity and confidentiality to all study participants, as well as making 
explicit that the questions had no right or wrong answers (Podsakoff et al., 2003). With this aim, we run the Harman's single factor test. Using varimax rotation, the results of an exploratory factor analysis with all the model variables showed that nine factors accounted for $67.4 \%$ of the total variance, with the first factor explaining only $12.2 \%$ of the variance, suggesting the absence of a single general factor in the data set (ibid).

\section{Results}

\section{Description of the Answers That Were Given}

Prior to examining our hypotheses, the overall data are presented, so that the reader shapes a better understanding of the current sample. Table 2, below, presents the Descriptive statistics for each of the variables examined.

Table 2: Descriptive statistics for the variables studied

\begin{tabular}{|l|c|c|}
\hline & Mean & Std. Dev. \\
\hline Psychological mobility & 3,39 & 0,80 \\
\hline Physical mobility & 3,00 & 0,81 \\
\hline Extended work involvement & 3,16 & 1,04 \\
\hline Maintain flexibility & 3,26 & 0,82 \\
\hline Seek mentoring & 3,42 & 0,74 \\
\hline Self-Presentation & 3,25 & 1,01 \\
\hline Career advancement & 3,32 & 1,14 \\
\hline Career Satisfaction & 3,36 & 0,78 \\
\hline
\end{tabular}

It appears that respondents in our sample are overall somewhat satisfied with their career and that they expect to advance in their career in the medium term. In relation to boundaryless career attitudes, it appears that respondents are more characterized by a psychological mobility than a physical mobility attitude. With regard to their career management behaviors, the mostly adopted career behavior is to seek mentoring, followed by maintain flexibility and self-presentation. Extended work involvement is the least adopted career management behavior.

In addition to that, it was deemed necessary that we control for the effect that various demographic traits have on the variables examined here. Specifically, we decided to see whether gender, age, education level and occupation are affecting the variables under study. In order to achieve this, t-tests and Analysis of Variance (ANOVA) were applied. The results of this part of our descriptive analysis (means by group for which a statistically significant difference was elaborated) are depicted in Tables 3 and 4. 
Table 3: Variables in which the difference of mean between the two genders is significant at the 0.05 level

\begin{tabular}{|l|l|r|c|}
\hline \multicolumn{1}{|c|}{ Variable } & \multicolumn{1}{c|}{ Gender } & \multicolumn{1}{c|}{$\begin{array}{c}\text { Mean of } \\
\text { Variable }\end{array}$} & Std. Dev. \\
\hline Career Satisfaction & Male & 0.1429 & 1.00499 \\
\hline & Female & -0.0821 & 1.01075 \\
\hline Extended Work Involvement (Career Behavior) & Male & 0.0964 & 0.99846 \\
\hline & Female & -0.1872 & 1.07486 \\
\hline
\end{tabular}

Table 4: Variables for which the mean is significantly different, by category examined (ANOVA results, $\mathrm{p}<0.05$ )

\begin{tabular}{|c|c|c|c|}
\hline Variable & & Mean of Variable & Std. Dev. \\
\hline & Age & & \\
\hline \multirow[t]{3}{*}{ Career Advancement } & born before 1960 & -0.511 & 1.11 \\
\hline & born from 1960-1979 & -0.202 & 0.94 \\
\hline & born after 1980 & 0.195 & 0.90 \\
\hline \multirow[t]{3}{*}{ Career Satisfaction } & born before 1960 & 0.234 & 0.98 \\
\hline & born from 1960-1979 & 0.054 & 0.97 \\
\hline & born after 1980 & -0.237 & 1.06 \\
\hline \multirow[t]{3}{*}{ Maintain Flexibility (Career Behavior) } & born before 1960 & -0.332 & 1.00 \\
\hline & born from 1960-1979 & -0.292 & 1.05 \\
\hline & born after 1980 & 0.193 & 0.90 \\
\hline \multirow[t]{3}{*}{ Physical Mobility (Career Attitude) } & born before 1960 & -0.399 & 0.95 \\
\hline & born from 1960-1979 & -0.115 & 1.03 \\
\hline & born after 1980 & 0.241 & 0.92 \\
\hline \multirow{4}{*}{ Seek Mentoring (Career Behavior) } & born before 1960 & -0.324 & 1.04 \\
\hline & born from $1960-1979$ & -0.183 & 1.08 \\
\hline & born after 1980 & 0.065 & 0.86 \\
\hline & Occupation & & \\
\hline \multirow{3}{*}{ Career Satisfaction } & Entrepreneur & 0.418 & 0.865 \\
\hline & Self- Employed & 0.255 & 0.944 \\
\hline & Employee & -0.013 & 0.996 \\
\hline \multirow{3}{*}{$\begin{array}{l}\text { PhysicalMobility } \\
\text { (Career Attitude) }\end{array}$} & Entrepreneur & -0.411 & 0.786 \\
\hline & Self- Employed & 0.138 & 1.120 \\
\hline & Employee & -0.156 & 1.001 \\
\hline \multirow{3}{*}{ Self-Presentation (Career Behavior) } & Entrepreneur & 0.080 & 0.973 \\
\hline & Self- Employed & -0.423 & 1.046 \\
\hline & Employee & -0.120 & 0.987 \\
\hline \multirow{4}{*}{$\begin{array}{l}\text { Extended Work Involvement } \\
\text { (Career Behavior) }\end{array}$} & Entrepreneur & 0.444 & 0.865 \\
\hline & Self- Employed & 0.257 & 0.899 \\
\hline & Employee & -0.175 & 1.085 \\
\hline & Education & & \\
\hline \multirow{2}{*}{ Career Satisfaction } & Primary & 0.099 & 0.775 \\
\hline & Secondary & -0.122 & 1.097 \\
\hline
\end{tabular}


Table 4. Continued

\begin{tabular}{|l|l|c|c|}
\hline \multicolumn{1}{|c|}{ Variable } & \multicolumn{1}{|c|}{ Age } & Mean of Variable & Std. Dev. \\
\hline & \multicolumn{1}{|c|}{} & & \\
\hline \multirow{4}{*}{$\begin{array}{l}\text { Physical Mobility } \\
\text { (Career Attitude) }\end{array}$} & Higher & 0.035 & 0.995 \\
\cline { 2 - 4 } & Postgraduate & 0.269 & 0.903 \\
\hline \multirow{4}{*}{$\begin{array}{l}\text { Self-Presentation } \\
\text { (Career Behavior) }\end{array}$} & Primary & -0.122 & 0.770 \\
\cline { 2 - 4 } & Secondary & -0.362 & 0.884 \\
\cline { 2 - 4 } & Higher & -0.049 & 1.017 \\
\cline { 2 - 4 } & Postgraduate & 0.109 & 1.102 \\
\hline \multirow{4}{*}{$\begin{array}{l}\text { Extended Work Involvement } \\
\text { (Career Behavior) }\end{array}$} & Primary & -0.686 & 1.197 \\
\cline { 2 - 4 } & Secondary & -0.279 & 1.107 \\
\cline { 2 - 4 } & Higher & -0.059 & 0.970 \\
\cline { 2 - 4 } & Postgraduate & -0.068 & 0.870 \\
\hline & Primary & -0.919 & 1.265 \\
\cline { 2 - 4 } & Secondary & 0.283 & 1.140 \\
\cline { 2 - 4 } & Higher & 0.041 & 0.964 \\
\cline { 2 - 4 } & Postgraduate & & 1.028 \\
\hline
\end{tabular}

The tests for difference of means for the variables under study (Tables 3 and 4) exhibited the existence of significant differences in both boundaryless career attitudes and career management behaviors on the one hand, and career outcomes on the other, for different demographic traits (gender, age, educational level and occupation). We will now discuss these differences which are interesting and worthy to be mentioned.

As depicted in Tables 3 and 4, several of the variables under study in the model that we set up to propose, differ significantly by given demographic characteristics. Men demonstrate higher career satisfaction than women, while they also appear to adopt to a larger extent a work involvement career strategy (t-tests for difference of means, $\mathrm{p}<0.05$, as depicted in Table 3 ). This agrees to previous findings on higher career satisfaction of men (Martins, Eddleston and Veiga, 2002), as well as on their higher work centrality in life (Mannheim, 1993). In addition to that (ANOVA results, Table 4), age was also found to affect the levels of several of the variables examined. As one would expect, the expectation to advance in career in the short term was found to be higher for younger people, most probably because these are in the beginning of their career and feel opportunities are open in order to advance. However, career satisfaction was higher for older people, as these are more prone to have achieved in several ways their career goals. At the same time, younger people appeared to adopt more than older people the maintain flexibility and the seeking mentoring career behaviors, while they also have a higher physical mobility career attitude. Occupation also had some relation with the variables under study, as entrepreneurs, followed by the self- employed exhibited higher career satisfaction and adopted to a higher extend than employees the extended work involvement career strategy. Entrepreneurs were also more probable to adopt a self- presentation career management behavior than 
the other two types of occupations. However, entrepreneurs also exhibited a lower physical mobility career attitude, than all the other occupations that we examined, most probably due to their high commitment to their own enterprise, operation and clients. Physical mobility was comparably higher in the case of self-employed, as they consider that they are not bound to any employer and that they tend to easily offer their services to any given client. Finally, education level was also found to relate to several of the variables under study. Career satisfaction was highest for people with postgraduate studies, most probably because their academic development allowed them to pursue better their career goals. At the same time, people with higher education completed (postgraduate studies), were more probable to be characterized by a physical mobility career attitude, and adopt a self- presentation and extended work involvement career strategy, than people with lower educational backgrounds. To sum up, a typical profile of the mostly satisfied from his/her career, would be a male, mature, entrepreneur, and with a postgraduate degree, respondent. Since our aim is not to identify the differences between demographic groups in each of the variables studied, the rest of our analysis will specifically focus on the effects of boundaryless career attitudes on career satisfaction and career advancement through the mediation of specific career management behaviors, for the total of the population examined (i.e. Greek employees) regardless of the demographic profile of the respondents.

After running all sets of analyses on Smart PLS, we concluded at a final model. All standard tests and indicators were studied and found to agree with expected standards. With regards to the measurement model, Reliability and Validity for all the latent variables inserted were assessed and established. Regarding Internal Consistency Reliability, the Cronbach's a was calculated and as shown in Table 5 that follows, it was found to range from 0.72 to 0.90 . Acceptable Indicator Reliability was also established through the study of factor loadings that all were over 0.4 . Convergent Validity (Unidimensionality) was also established through the Average Variance Explained (AVE) that was found to be over or around 0.5 according to the strict Fornell \& Larcker criterion (Bray and Macneil, 2011). Finally Discriminant Validity was also established through the study of cross-loadings being lower than loadings on the assigned latent variable. We also established the discriminant validity with the Fornell \& Larcker criterion of AVE of each latent variable being higher than its squared correlations with all other latent variables (Fornell and Larcker, 1981). This was sustained in all latent variables, except for the maintain flexibility career strategy, as this variable had comparable to its own AVE correlations with other variables. 
Table 5: Quality Criteria for Measurement Model

\begin{tabular}{|l|c|c|c|c|}
\hline & Cronbach's Alpha & Composite Reliability & $\mathbf{R}^{2}$ & AVE \\
\hline Psychological Mobility & 0,87 & 0,90 & 0,00 & 0,53 \\
\hline Physical Mobility & 0,71 & 0,81 & 0,00 & 0,46 \\
\hline Extended Work Involvement & 0,77 & 0,87 & 0,17 & 0,68 \\
\hline Maintain Flexibility & 0,76 & 0,85 & 0,26 & 0,59 \\
\hline Self-Presentation & 0,76 & 0,89 & 0,06 & 0,80 \\
\hline Seeking Mentoring & 0,77 & 0,84 & 0,40 & 0,47 \\
\hline Career Satisfaction & 0,91 & 0,93 & 0,20 & 0,61 \\
\hline Career Advancement & 1,00 & 1,00 & 0,32 & 1,00 \\
\hline
\end{tabular}

With regards to the Structural Model, both the size of betas and Effect Size and therefore substantiality of the betas were established for each dependent variable. Table 4 depicts the effect sizes found for each dependent variable. An Effect Size higher than 0.35 is considered to signify a strong effect. An effect size between 0.15 and 0.35 is considered to be a moderate effect, while lower effect sizes over 0.02 are considered to signify weak effects (Parker et al., 2009).

\section{Boundaryless Career Attitudes on Career Outcomes}

With regard to boundaryless career attitudes and career outcomes some interesting findings can be reported. First, there is a strong direct effect of the psychological mobility on career advancement and a moderate effect on career satisfaction (H1). Contrary to our expectations, a physical mobility career attitude has a moderate negative direct effect on career satisfaction, while the direct effect on career advancement is weak $(\mathrm{H} 2)$.

\section{Career Strategies on Career Outcomes}

As we expected, both task-oriented career strategies were positively related with career outcomes. However, the two task-oriented career behaviors lead to different subjective career outcomes. Thus, extended work involvement has a moderate effect in predicting career satisfaction, while adopting behaviors to maintain flexibility has a moderate association with expectations to advance in career (H3). Both relationship-oriented career strategies had a moderate direct effect on career advancement $(\mathrm{H} 4)$

\section{Boundaryless Career Attitudes on Career Strategies}

There is a strong direct effect of the psychological mobility as a career attitude on three career strategies, namely extended work involvement, maintain flexibility and 
seek mentoring, while a moderate direct effect on self-presentation has been identified (H5). Moreover, self-presentation has a strong direct effect on the seeking mentoring career behavior.

Contrary to what we expected, the physical mobility attitude had only weak direct effects with all career strategies and most notably a weak negative effect with the career behavior of seeking mentoring (H5).

This is the case for the direct effects of the psychological mobility as a career attitude on the maintain flexibility, seek mentoring, and work involvement as career strategies (H5), and on career advancement (H1). A strong effect is also identified between self-presentation and seeking mentoring as career behaviors. We notice the existence of moderate effects in the prediction of career satisfaction from a psychological mobility career attitude (H1) and extended work involvement as a career strategy (H3), while a physical mobility career attitude seems to have a negative moderate effect on career satisfaction (H2). Three strategies of career development, i.e. maintain flexibility (H3), seek mentoring and self- presentation (H4) have moderate effects in the prediction of career advancement. All the other effects presented in Table 6, below, are weak, yet significant.

Table 6: Effect sizes

\begin{tabular}{|c|c|c|c|c|c|c|}
\hline & 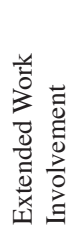 & 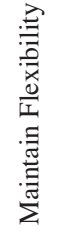 & 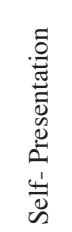 & 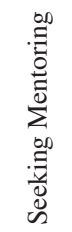 & 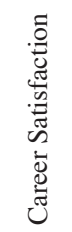 & 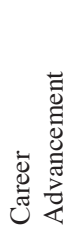 \\
\hline Psychological Mobility & 0,42 & 0,51 & 0,39 & 0,25 & 0,33 & 0,40 \\
\hline Physical Mobility & $-0,13$ & 0 & $-0,16$ & $-0,11$ & $-0,29$ & 0,08 \\
\hline Extended Work Involvement & 0 & 0 & 0 & 0 & 0,12 & 0 \\
\hline Maintain Flexibility & 0 & 0 & 0 & 0 & 0,17 & 0,20 \\
\hline Self-Presentation & 0 & 0 & 0 & 0 & 0,02 & 0,21 \\
\hline Seeking Mentoring & 0 & 0 & 0,51 & 0 & 0,02 & 0,21 \\
\hline Career Satisfaction & 0 & 0 & 0 & 0 & 0 & 0 \\
\hline Career Advancement & 0 & 0 & 0 & 0 & 0,09 & 0 \\
\hline
\end{tabular}

The statistical significance of path coefficients was established through two tailed t-tests on bootstrapping findings. On 1000 bootstrapping samples, most coefficients of the structural model were found to be significant at the 0.05 level. Those that were not found to be significant at the 0.05 level (and which also exhibited weak effects) were eventually excluded from the final model. Based on this decision, our final structural model takes the form depicted in Figure 2 that follows. Table 7 summarizes the correlations between the variables in the final model. 
Figure 2: Final structural model, based on substantiality and significance of betas

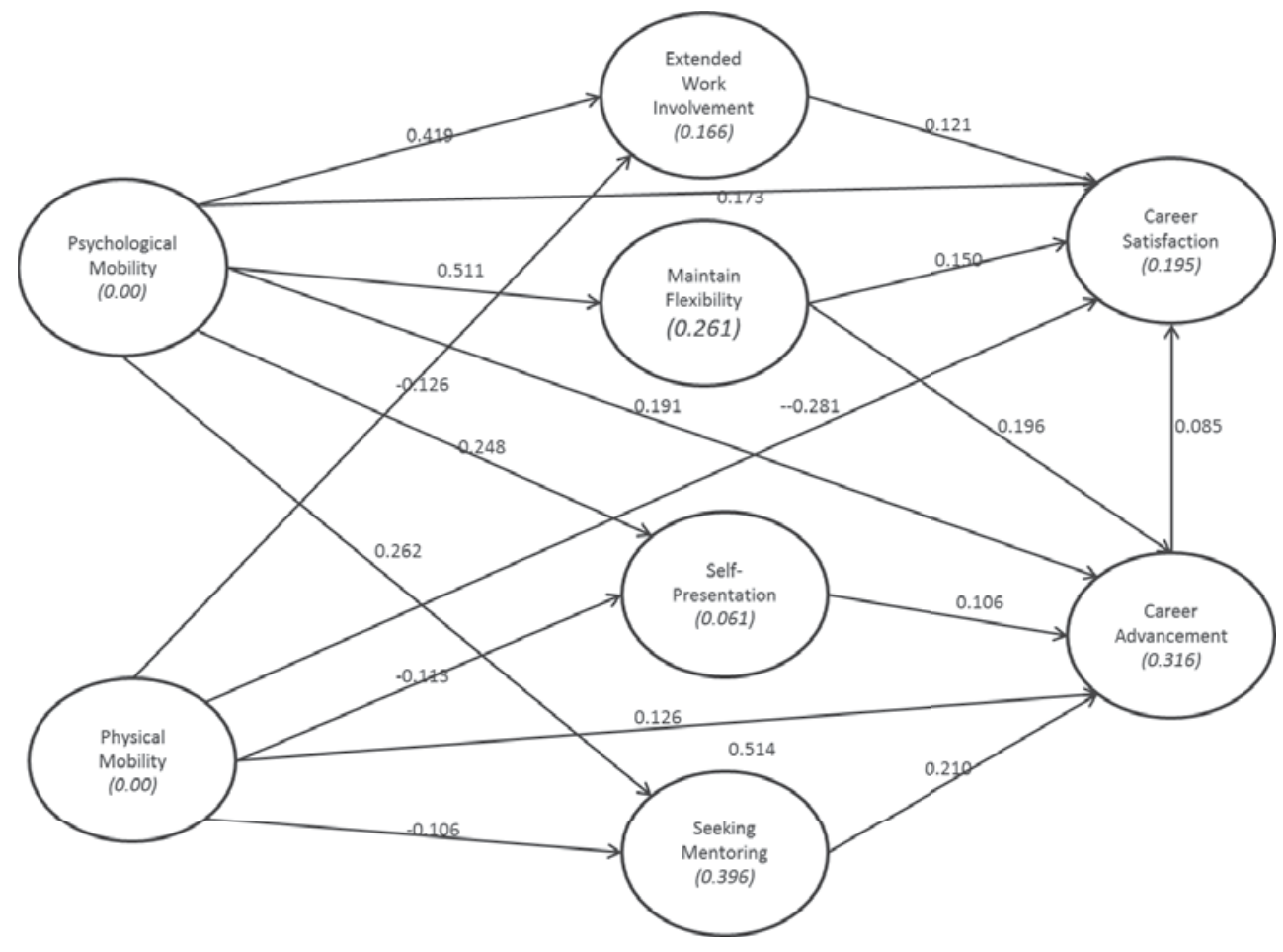

Table 7: Correlations between latent variables

\begin{tabular}{|c|c|c|c|c|c|c|c|c|}
\hline & 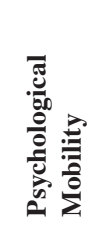 & 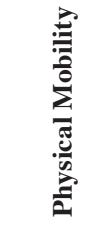 & 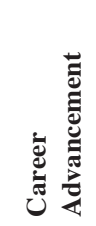 & 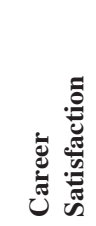 & 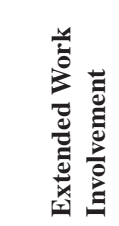 & 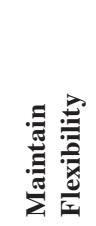 & 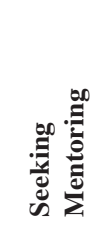 & 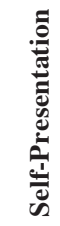 \\
\hline Psychological Mobility & 1 & & & & & & & \\
\hline Physical Mobility & 0,235 & 1 & & & & & & \\
\hline Career Advancement & 0,418 & 0,178 & 1 & & & & & \\
\hline Career Satisfaction & 0,267 & $-0,207$ & 0,209 & 1 & & & & \\
\hline $\begin{array}{l}\text { Extended Work } \\
\text { Involvement }\end{array}$ & 0,389 & $-0,028$ & 0,271 & 0,265 & 1 & & & \\
\hline Maintain Flexiblity & 0,511 & 0,145 & 0,455 & 0,273 & 0,301 & 1 & & \\
\hline Seeking Mentoring & 0,351 & $-0,073$ & 0,423 & 0,230 & 0,349 & 0,478 & 1 & \\
\hline Self-Presentation & 0,221 & $-0,055$ & 0,341 & 0,221 & 0,266 & 0,399 & 0,578 & 1 \\
\hline
\end{tabular}




\section{Mediating Effects of Career Strategies}

Regarding the Mediating effects included in the model, the Baron and Kenny methodology was applied (Van Hooft and De Jong, 2009). First, (a) it was established that the direct effect of the independent on the dependent variables was significant (without the mediator), then (b) that the indirect effect via the mediator variable is also significant, and finally (c) that the direct effect becomes less significant with the inclusion of the mediator variable in the model.

For the first two tests, (a) and (b), t-tests on 1000 bootstrapping samples and the original effects were run for the direct effect and for the indirect effect (Ho: coefficients $=0$ ). For establishing (c) that the direct effect becomes less significant with the inclusion of the mediators, the Variance Accounted For was computed, where VAF= Indirect Effect/Total Effect. For the examined mediating effects, the Variance Accounted For was as depicted in Table 8, below.

Table 8: Type of mediation established, according to the three tests of Baron and Kenny

\begin{tabular}{|c|c|c|c|c|c|}
\hline Mediator & Relationship & $\begin{array}{c}\text { Total } \\
\text { Effect }\end{array}$ & $\begin{array}{c}\text { Indirect } \\
\text { Effect }\end{array}$ & VAF & $\begin{array}{c}\text { Existence of } \\
\text { mediation }\end{array}$ \\
\hline \multirow{2}{*}{$\begin{array}{l}\text { Extended Work Involvement } \\
\text { (Career Behavior) }\end{array}$} & $\begin{array}{l}\text { Psychological mobility on } \\
\text { career satisfaction }\end{array}$ & 0,3335 & 0,051 & $15,2 \%$ & no mediation \\
\hline & $\begin{array}{l}\text { Physical mobility on career } \\
\text { satisfaction }\end{array}$ & $-0,2866$ & $-0,015$ & $5,3 \%$ & no mediation \\
\hline $\begin{array}{l}\text { Maintain Flexiblity (Career } \\
\text { Behavior) }\end{array}$ & $\begin{array}{l}\text { Psychological mobility on } \\
\text { career advancement }\end{array}$ & 0,398 & 0,100 & $25,2 \%$ & partial mediation \\
\hline \multirow{4}{*}{$\begin{array}{l}\text { Self-Presentation (Career } \\
\text { Behavior) }\end{array}$} & $\begin{array}{l}\text { Physical mobility on career } \\
\text { satisfaction }\end{array}$ & $-0,286$ & $-0,024$ & $8,4 \%$ & no mediation \\
\hline & $\begin{array}{l}\text { Psychological mobility on } \\
\text { career satisfaction }\end{array}$ & 0,333 & 0,004 & $1,3 \%$ & no mediation \\
\hline & $\begin{array}{l}\text { Psychological mobility on } \\
\text { career advancement }\end{array}$ & 0,398 & 0,052 & $13,3 \%$ & no mediation \\
\hline & $\begin{array}{l}\text { Physical mobility on career } \\
\text { advancement }\end{array}$ & 0,084 & $-0,024$ & $-28,7 \%$ & partial mediation \\
\hline \multirow{2}{*}{$\begin{array}{l}\text { Seeking Mentoring (Career } \\
\text { Behavior) }\end{array}$} & $\begin{array}{l}\text { Psychological mobility on } \\
\text { career advancement }\end{array}$ & 0,398 & 0,082 & $20,5 \%$ & partial mediation \\
\hline & $\begin{array}{l}\text { Physical mobility on career } \\
\text { advancement }\end{array}$ & 0,084 & $-0,034$ & $-41,0 \%$ & partial mediation \\
\hline
\end{tabular}

The above finding means that the inclusion of the mediators substantially changes the relationship between the independent variables of career attitudes on the dependent ones, i.e. career advancement and career satisfaction. Therefore, individuals with psychological and physical mobility career attitudes enhance their options to succeed and advance in their career through specific career strategies. Specifically, a person high in psychological mobility increases his/her chances of career advance- 
ment through maintaining flexibility and seeking mentoring as career behaviors. Self- presentation as a career behavior also partly mediates the relationship between the physical mobility career attitude and career advancement, meaning that their direct relation is diminished after the inclusion of the self-presentation strategy. A partial mediation also exists in the relation between physical mobility and career advancement when the seeking mentoring career behavior is taken into account. As physically mobile individuals tend not to adopt seeking mentoring or self- presentation career strategies, this diminishes their chance to advance early in their career.

\section{Discussion}

This study examined the impact of boundaryless career attitudes on career outcomes and the mediating role of career management behaviors. The contribution of this paper lies on the fact that it expands the existing literature by constructing a composite model to study the behavioral paths that people with boundaryless career attitudes may use to experience career success. Even though the concept of the boundaryless career is not new in the career literature, empirical research examining the impact of a boundaryless career attitude on career outcomes is scarce (Eby et al, 2003). By studying the behavioral options individuals with boundaryless career attitudes adopt to achieve career objectives we understand better the concepts of psychological and physical mobility.

A general comment we can make in this direction is that even though we have examined both psychological and physical mobility attitudes, our results help us understand better the dynamics of the psychological mobility attitude which is less studied (Sullivan and Arthur, 2006). Next, we will first discuss the direct relationships found, followed by the mediated ones, for each career attitude dimension.

a) Psychological Mobility. Our findings support our hypothesis that those with a psychological mobility are more likely to expect career advancement and report higher levels of career satisfaction. This is in line with the Arthur et al's (2005) argument that subjective career success indicators may be more relevant for the psychological mobility dimension. A person with a boundaryless career mindset is inclined to create and sustain active working relationships across boundaries both within and outside the organization (Briscoe et al, 2006). Hierarchical advancement may not be the main focus in career development for such individuals. Indeed, no relationship has been found with the objective career success measure (position in the hierarchy) we used.

An individual with a psychological mobility career attitude needs to understand the landscape and monitor his/her behavior to effectively promote his/her career goals. Our results confirm our hypotheses and indicate that a person with psychological mobility orientation uses a variety of career management behaviors. First, 
the individual is more likely to engage in behaviors that expand his/her skills, and maintain his/her flexibility. Skill-building and training opportunities may satisfy the needs for autonomy, variety and novelty individuals with a psychological mobility have (Segers et al, 2008). Individuals using this set of behaviors are open in their career choices and develop skills that make them flexible. In fact, from the four career management strategies used in this research design, this is the only one that has a moderate direct effect on career satisfaction. Eby et al (2003) support that openness to experience and "knowing how" are related to career success. Our results failed to support a significant relationship between the behaviors that individuals use to maintain flexibility and career satisfaction, but they support a significant relationship with expectations to career advancement. Moreover, the use of activities to maintain flexibility strengthens the relationship between psychological mobility and career advancement. Thus, individuals with psychological mobility attitude who use maintain flexibility behaviors are more likely to perceive advancement in their career.

Our findings support the hypothesis that individuals with psychological mobility adopt relationship oriented career strategies by asking for feedback, coaching and building networks. These individuals are more likely to expect to get promoted in the near future. This is in line with previous research that supports that mentoring has a positive impact on career advancement in Greece (Apospori et al, 2006). However, we did not find any direct significant relationship with career satisfaction. Mentoring/networking behaviors may be seen as more efficient as traditional indicators for career success and people may use it, but this does not lead to career satisfaction. Previous research findings in the career literature are inconclusive. According to a number of researchers, mentoring, networking and "knowing whom" are important predictors of career satisfaction (Colakoglu, 2011; Eby et al, 2003; Kuijpers et al, 2006). Individuals with psychological mobility have higher need for affiliation which may drive them to pursue work-related relationships (Segers et al, 2008). Moreover, "knowing whom" is positively related to career autonomy and negatively to career insecurity which leads to career satisfaction (Colakoglu, 2011). However, De Vos and Soens (2008) did not find any support for the direct relationship between the career self-management behaviors of networking and visibility and career satisfaction and employability. Nikandrou et al (2008) also failed to find any significant relationship between mentoring/networking and career satisfaction for women in Greek organizations. Further research is needed to better understand the dynamics between psychological mobility, relational-oriented career behaviors and career satisfaction. An individual with a psychological mobility career attitude uses self-presentation behaviors to a lesser degree and those individuals who use these career management behaviors are more likely to also use mentoring behaviors.

Extended work involvement implies that the individual is more preoccupied with career and increases the amount of effort and time devoted to work. It seems that a psychological mobile individual is willing to exert additional effort to work in dif- 
ferent projects, with different people. From the four career management behaviors used here, this is the only one with no mediating effects between boundaryless career attitudes and career outcomes. It seems that when people feel psychologically safe both in terms of their work as in their ability to develop skills and relationships, they are more psychologically mobile.

According to Briscoe and Hall (2006) the main characteristic of a person with a psychological mobility attitude is his/her emphasis on creating and sustaining active relationships across organizational boundaries. Our results portray an individual very much interested in promoting his/her career and satisfaction through continuous learning, hard work, and building relationships with experienced people and superiors to get feedback and guidance. The individuals with a psychological mobile career attitude are not afraid of the non-existence of job alternatives. It seems that they fulfill their need for security from their inner strengths, their openness to experience and learning through their collaboration with others. They enjoy variety in their work as it helps them learn, grow and remain flexible. Their behavioral choices show that they create their options by working hard, setting career goals, remaining flexible and actively seeking mentoring and presenting their accomplishments. It seems that they form this attitude as they want to become more resilient in a hostile environment.

b) Physical Mobility. No strong direct effects were observed for individuals' physical mobility attitude. To our surprise and contrary to our hypothesis we found a moderate negative direct relationship with career satisfaction. Moreover, physical mobility was not directly associated with expectations for career advancement. However, there was a significant negative relationship when relational career behaviors, such as seeking mentoring and self-presentation were employed. As unemployment rises, the possibilities to actually move across organizations is limited. In times of economic crisis, status, money and promotion possibilities are worsening, thus making individual more reluctant to move. Individuals may perceive that they have the capacity to make transitions (Sullivan and Arthur, 2006) but they do not have the opportunities to move physically. Moreover, these findings support Briscoe et al (2006) argument that people may hold boundaryless attitudes but do not have the inclination to move.

\section{The Greek Context}

Sullivan and Arthur (2006) propose that cultural differences may influence both psychological and physical mobility (p. 26). Thus, we will also discuss some of our findings in the light of the Greek cultural and economic context. People in collectivist countries emphasize job security and are more likely to exhibit psychological mobility (Sullivan and Arthur, 2006). Indeed, our findings support this proposition. According to GLOBE'S findings Greeks value collectivism (Nikandrou et al, 2003). 
Recent research on organizational culture from Greece has shown that most Greek organizations rank high in in-group collectivism, meaning that the feeling of community and the identification with common, in-group goals is quite strong as a cultural dimension, both as a practice and as a value (Galanaki and Papalexandris, 2013). Our results show that the individuals with a psychological mobility who seek mentoring do not report higher satisfaction with their careers. A possible explanation lies in the fact that in the Greek context people are anyway expected to develop relationships and close bonds within their inner groups inside the organization, without this necessarily meaning that they substantially enhance their career satisfaction through that. It may also mean that a person with a psychological mobility attitude does not conform easily to the general in-group identification cultural imperative, as most probably a boundaryless- feeling individual is more prone to think out-of-the box and abstain from identifying with in-groups within an organization.

Moreover, we did not find any direct significant relationship of seeking mentoring with career satisfaction. A possible explanation for this might be the Greek context that does not promote mentorship and network building. The Greek environment characterized by high power distance impedes both upward and downward communication and makes it harder for individuals to attempt to seek mentoring and develop their networks with higher in the hierarchy individuals. (Papalexandris and Panayotopoulou, 2004; Papalexandris, 2007). Moreover, mentoring/networking behaviors may be seen as more efficient as traditional indicators for career success and people may use it, but this does not lead to career satisfaction.

This study reports low levels of physical mobility. Greeks have been found to score low on work mobility intention and practice, both in terms of professional (Danish Technological Institute, 2008) and of geographical mobility. In fact, Greece scores at the lowest places among European countries on both these indicators and definitely at lower than the EU average levels. In addition to that, recent research has established that Greeks, from all the organizational commitment indicators score highest on the continuance commitment indicator (Galanaki, 2013), i.e. the consideration on the future alternatives if and when one does not stay with his employer. This could partly explain the fact that Greeks who are physically mobile are actually dissatisfied with their career: although this is an attitude that they endorse, there is a cultural discrepancy in the way Greek careers are generally managed. A possible explanation for this may lie in the societal context and the high unemployment rates in Greece.

\section{Limitations and Future Research}

Our study did have some limitations. The use of cross-sectional data in causal modeling makes it difficult to unequivocally determine the direction of the relationships found. We used only self-report data and there is a risk for common method variance. 
Future research should include data coming from other parties such as employee's supervisor. In this study, we used a single item to measure individuals' expectations to advance, to examine their attitude towards moving in their career. We did not differentiate whether individuals expected to advance internally or externally. However, it seems that subjective beliefs of career advancement are important outcomes in the formation of boundaryless career attitudes. Future research should examine this issue by offering more precise operationalization in the career advancement measure.

Previous research has suggested that individuals at different stages in their careers have different expectations and employ different career management behaviors (Sturges et al, 2000). Further research is needed to better understand whether individuals at different career stages differ in their attitudes towards mobility, both psychological and physical and whether this difference make them evaluate and use different career management strategies. In this paper, the emphasis was on understanding how individuals with boundaryless career attitudes manage their careers by performing certain activities that lead to certain career outcomes. Even though a boundaryless career focuses on self-reliant career behaviors, organizations still have career development schemes that help individuals manage their careers. Moreover, within flatter organizational structures, where team-work and projects require from people to be psychological mobile, organizations need to facilitate, train and manage individuals through relevant career schemes. Future research should investigate how individuals with a boundaryless attitude use both organizational and self-management career activities. Also, further research is needed to understand the impact of context and societal culture on individuals' career attitudes, behaviors adopted and outcomes achieved.

\section{Conclusion}

A person with a boundaryless career attitude may pursue a "traditional, organizational" career, a "boundaryless" one, or a combination of both to some degree. No matter which career path the person takes the dynamics involved in the process may be similar, as people with boundaryless career attitudes may be predisposed to certain behavioral manifestations. Our results showed that a person with a psychological mobility attitude is more likely to achieve career satisfaction through remaining flexible in his/her career. Expectations for advancement are strengthened when a person maintains flexibility through continuous learning and gets guidance and support from his/her superior. This knowledge is very important for practitioners and managers in enhancing a psychologically mobile career attitude. Providing opportunities for training, skill development and challenging work make people feel more psychologically safe which may help them develop a more boundaryless career attitude. Moreover, individuals need to be exposed to superiors and get feedback and 
guidance. Managers need to understand their role as mentors and develop soft skills that help them build relationships with their peers. As most of the career management behaviors an individual with a boundaryless mindset employee increase expectations to career advancement, managers and HR department need to monitor these expectations and clearly communicate the career development systems.

\section{REFERENCES}

Apospori, E., Nikandrou, I., and Panayotopoulou, L. (2006), “Mentoring and women's career advancement in Greece", Human Resource Development International, Vol.9, No, 4, pp.509-527.

Abele, A.E., and Spurk, D. (2009). 'The longitudinal impact of self-efficacy and career goals on objective and subjective career success", Journal of Vocational Behavior, Vol.74, pp.53-62.

Allen, T.D., Eby, L.T., Poteet, M.L., and Lima, L. (2004), "Career benefits associated with mentoring for protégés: A meta-analysis”, Journal of Applied Psychology, Vol.89, pp.127-136.

Arthur, M.B., Hall, D.T., and Lawrence, B.S. (1989), Handbook of career theory, Cambridge University Press, New York, NY.

Arthur, M.B., Khapova, S.N., and Wilderom, C.P.M. (2005), "Career success in a boundaryless career world”, Journal of Organizational Behavior, Vol.26, pp.177-202.

Arthur, M.B., and Rousseau, D. M. (1996), "A career lexicon for the 21st century”, Academy of Management Executive, Vol.10, No.4, pp.28-39.

Bray, M., and MacNeil, J. (2011) "Individualism, Collectivism, and the Case of Awards in Australia", Journal of Industrial Relations, Vol.53, pp.149-167.

Briscoe, H. P., \& Hall, D. T. (2002). "The Protean orientation: creating the adaptable workforce necessary for flexibility and speed". Paper given at the Academy of Management, Denver.

Briscoe, J.P., \& Hall, D.T. (2006). "The interplay of boundaryless and protean careers: Combinations and implications". Journal of Vocational Behavior, Vol.69, pp.4-18.

Briscoe, J. P., Hall, D. T., and Frautschy Demuth, R. L. (2006), "Protean and boundaryless careers: An empirical exploration", Journal of Vocational Behavior, Vol.69, pp. 30-47.

Brunetto, Y., Teo, S. T. T., Shacklock, K., and Farr-Wharton, R. (2012), "Emotional intelligence, job satisfaction, well-being and engagement: explaining organisational commitment and turnover intentions in policing", Human Resource Management Journal, Vol.22, pp.428-441.

Colakoglu, S.N. (2011), "The impact of career boundarylessness on subjective career success: The role of career competencies, career autonomy, and career insecurity", Journal of Vocational Behavior, Vol.79, pp.47-59.

Danish Technological Institute (2008), "Job Mobility in the European Union: Optimising its Social and Economic Benefits", in Policy and Business Analysis, European Commission - Directorate General for Employment Social Affairs and Equal Opportunities (ed.).

De Vos, A., and Soens, N. (2008), "Protean attitude and career success: The mediating role of self-management", Journal of Vocational Behavior, Vol.73, pp.449-456.

Eby, L.T., Butts, M., and Lockwood, A. (2003), "Predictors of success in the era of the boundaryless career", Journal of Organizational Behavior, Vol.24, pp.689-708.

Eurobarometer (2010), "Geographical and labour market mobility", in Eurobarometer, European Commission (Ed).

Fornell, C., and Larcker, D. F. (1981), "Structural Equation Models with Unobservable Variables and Measurement Error: Algebra and Statistics", Journal of Marketing Research, Vol.18, pp.382-388. 
Galanaki, E. (2013), "Gender and the Importance of Fringe Benefits: Exploring their Link with Organizational Commitment and Job Satisfaction", paper presented at the European Academy of Management Conference, Istanbul, Turkey.

Galanaki, E., and Papalexandris, N. (2013), "The Critical Role of In-Group Collectivism and Humane Orientation for Employee Commitment and Satisfaction". Available at SSRN: http://ssrn. com/abstract=2325387 or http://dx.doi.org/10.2139/ssrn.2325387.

Gould, S., and Penley, L. (1984), "Career strategies and salary progression: a study of their relationships in a municipal bureaucracy", Organizational Behavior and Human Performance, Vol. 34, pp. 244-65.

Greenhaus, J.H., Callanan, G.A., and Godshalk, V.M. (2000), Career Management, The Dryden Press Harcourt College Publishers, 3rd ed., Hinsdale, IL.

Greenhaus, J. H., Parasuraman, S., and Wormley, W. M. (1990), "Effects of Race on Organizational Experience, Job Performance Evaluations, and Careeer Outcomes “, Academy of Management Journal, Vol.33, pp.64-86.

Gunz, H.P., and Heslin, P.A. (2005), "Reconceptualizing career success", Journal of Organizational Behavior, Vol.26, pp.105-111.

Gutrhie, J. P., Coate, C. J., and Schwoerer, C. E. (1998), "Career management strategies: the role of personality”, Journal of Managerial Psychology, Vol.13, pp371 - 386.

Hair, J. F., Ringle, C. M., and Sarstedt, M. (2013a), "Partial Least Squares Structural Equation Modeling: Rigorous Applications, Better Results and Higher Acceptance “, Long Range Planning, Vol.46, forthcoming (online available).

Hair, J. F., Hult, G. T. M., Ringle, C. M., and Sarstedt, M. (2013b), A Primer on Partial Least Squares Structural Equation Modeling (PLS-SEM), Sage, Thousand Oaks, CA.

Hair, J. F., Ringle, C. M., and Sarstedt, M. (2012), "Partial Least Squares: The Better Approach to Structural Equation Modeling?”, Long Range Planning, Vol.45, pp.312-319.

Hall, D.T. (1996), "Protean careers of the 21st century", Academy of Management Executive, Vol.10, No.4, pp.8-16.

Higgins, M.C., and Kram, K.E. (2001), "Reconceptualizing mentoring at work: a developmental network perspective", Academy of Management Review, Vol. 26, pp. 264-288.

Judge, T. A., Cable, D. M., Boudreau, J.W., and Bretz, R. D. (1995), "An empirical investigation of the predictors of executive career success", Personnel Psychology, Vol.48, pp.485-519.

King, Z. (2004), ,Career self-management: Its nature, causes and consequences”, Journal of Vocational Behavior, Vol.65, pp.112-133.

King, Z. (2001), "Career self-management: A framework for guidance of employed adults”, British Journal of Guidance and Counselling, Vol.29, No.1, pp.65-78.

Kuijpers, M.A.C.T., Schyns, B., and Scheerens, J. (2005), "Career competencies for career success", The Career Development Quarterly, Vol.55, pp.168-178.

Lee, P. (2002), "Career goals and career management strategy among information technology professionals", Career Development International, Vol. 7 No. 1, pp. 6-13.

Martins, L. L., Eddleston, K. A., and Veiga, J. F. (2002), "Moderators of the Relationship between Work-Family Conflict and Career Satisfaction”, Academy of Management Journal, Vol.45, pp.399-409.

Mannheim, B. (1993), "Gender and the effects of demographics, status and work values on work centrality", Work and Occupations, Vol.20 No.1, pp. 3-22.

Nabi, G. (2003), "Situational characteristics and subjective career success: the mediating role of career-enhancing strategies", International Journal of Manpower, Vol. 24 No. 3, pp. 653-71.

Ng, T.W.H., Eby, L.T., Sorensen, K.L., and Feldman, D.C. (2005), "Predictors of objective and subjective career success: A meta- analysis”, Personnel Psychology, Vol.58, 367-408. 
Nikandrou, I., Panayotopoulou, L., and Apospori, E. (2008), “The Impact of Individual and Organizational Characteristics on Work-Family Conflict and Career Outcomes". Journal of Managerial Psychology, Vol.23, No.5, pp.576-598.

Nikandrou, I., Apospori, E, and Papalexandris, N. (2003), "Cultural and leadership similarities and variations in the southern part of the European Union", Journal of Leadership and Organizational Studies, Vol.9, No.3, pp.61-84.

Papalexandris, N. (2007), "Greece, from Ancient Myths to Modern Realities", in Chhokar, J.C., Brodbeck, F.C., and House, R.J. (Ed), Culture and Leadership Across the World: The GLOBE Book of In-Depth Studies of 25 Societies, ch. 21, Lawrence Erlbaum Associates, Mahaw, N.J..

Parker, R. S., Haytko, D. L., and Hermans, C. M. (2009), “Individualism and collectivism: Reconsidering old assumptions", Journal of International Business Research, Vol.8, pp.127-139.

Podsakoff, P.M., Mackenzie, S. B., Lee, J.-Y., and Podsakoff, N. P. (2003), "Common Method Biases in Behavioral Research: A Critical Review of the Literature and Recommended Remedies", Journal of Applied Psychology, Vol.88, pp.879-903.

Ringle, C. M., Sarstedt, M., and Straub, D. W. (2012), "A Critical Look at the Use of PLS-SEM”, MIS Quarterly, Vol.36, pp.iii-xiv.

Ringle, C. M., Wende, S., and Will, A. (2005), SmartPLS 2.0, www.smartpls.de.

Segers, J., Inceoglu, I., Vloeberghs, D., Bartram, D., and Henderickx, E. (2008), "Protean and boundaryless careers: A study on potential motivators", Journal of Vocational Behavior, Vol.73, pp.212-230.

Sturges, J. Guest, D., Conway, N., and Mackenzie Davey, K. (2002), “A longitudinal study of the relationship between career management and organizational commitment among graduates in the first ten years at work", Journal of Organizational Behavior, Vol. 23, pp.731-748.

Sullivan, S.E., and Arthur, M.B. (2006), "The evolution of the boundaryless career concept: Examining physical and psychological mobility", Journal of Vocational Behavior, Vol. 69, pp.19-29.

Super, D. E. (1980), “A Life-Span, Life-Space Approach to Career Development”, Journal of Vocational Behavior, Vol. 16, pp.282-298.

Van Hooft, E. A. J., and De Jong, M. (2009), "Predicting job seeking for temporary employment using the theory of planned behavior: The moderating role of individualism and collectivism", Journal of Occupational \& Organizational Psychology, Vol.82, pp.295-316.

Wanberg, C.R., Welsh, E.T. and Hezlett, S.A. (2003), "Mentoring research: a review and dynamic process model", in Martocchio, J.J. and Ferris, G.R. (Ed.), Research in Personnel and Human Resources Management, Elsevier Science, Oxford, Vol. 22, pp. 39-124.

Wilensky, (1961), "Orderly careers and social participation: the impact of work history on social integration in the middle mass", American Sociological Review, Vol.26, pp.521-539. 


\section{APPENDIX}

Table A1: Pattern matrix factor loadings for the four-factor solution of the Career Management Behaviors Scale

\begin{tabular}{|c|c|c|c|c|c|}
\hline \multirow{4}{*}{$\begin{array}{l}\text { Extended } \\
\text { Work } \\
\text { Involvement }\end{array}$} & Take your work home with you. & 0,8642 & & & \\
\hline & Work at your job beyond normal work hours. & 0,8102 & & & \\
\hline & $\begin{array}{l}\text { Spend considerable non-work hours thinking about } \\
\text { your job. }\end{array}$ & 0,8058 & & & \\
\hline & $\begin{array}{l}\text { Develop skills which may be needed in future career } \\
\text { positions }\end{array}$ & & 0,8521 & & \\
\hline \multirow{4}{*}{$\begin{array}{l}\text { Maintain } \\
\text { Flexibility }\end{array}$} & Keep my career options open & & 0,7789 & & \\
\hline & $\begin{array}{l}\text { Assume leadership in work areas where there seems to } \\
\text { be no leadership }\end{array}$ & & 0,7494 & & \\
\hline & $\begin{array}{l}\text { Develop expertise in areas critical to the department's } \\
\text { operation. }\end{array}$ & & 0,672 & & \\
\hline & Get career guidance from supervisors. & & & 0,7659 & \\
\hline \multirow{6}{*}{$\begin{array}{l}\text { Seek } \\
\text { Mentoring }\end{array}$} & Work hard when you know superiors will see results. & & & 0,7326 & \\
\hline & $\begin{array}{l}\text { Get career guidance from experienced people in the } \\
\text { organization. }\end{array}$ & & & 0,7249 & \\
\hline & Make your superiors aware of your career objectives. & & & 0,651 & \\
\hline & Make your boss aware of assignments you want & & & 0,6034 & \\
\hline & $\begin{array}{l}\text { Obtain broadly based work experiences in the } \\
\text { organization }\end{array}$ & & & 0,6008 & \\
\hline & Make superiors aware of accomplishments. & & & & 0,9232 \\
\hline $\begin{array}{l}\text { Self- } \\
\text { Presentation }\end{array}$ & Present yourself as a person who "gets things done". & & & & 0,8694 \\
\hline
\end{tabular}

Source: Adapted from Guthrie et. al. (1998). 
